\title{
電極材料としてのダイヤモンド薄膜 \\ Diamond Thin Films for Electrode Material
}

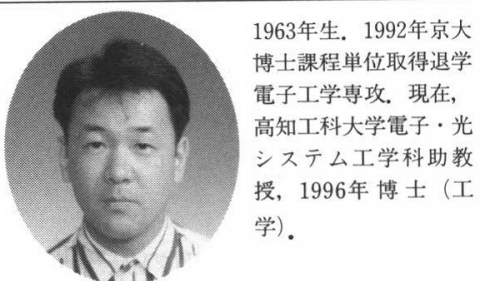

\キーワード：ダイヤモンド, 薄膜, 気相合成法, 電極材料, 冷陰極, 電子親和力

八 $\underset{\text { Akimitsu } \stackrel{\text { 章 }}{\text { Hatta }} \text { 光 }}{ }$

\section{1.はじめに}

ダイヤモンドは電気・電子材料としてきわめて魅力的 な物性を多く持っている。とくに，気相合成で得られる 薄膜ダイヤモンドは電界放射型ディスプレイ（FED） などの泠陰極材料として期待されている。本稿では, 薄 膜ダイヤモンドの人工合成技術の現状とダイヤモンドの 持つ特異な表面電子物性, さらに電子放出材料としての 応用の可能性について紹介する。

\section{2.ダイヤモンドの人工合成}

ダイヤモンドの人工合成は1950年代に高温高圧法に よって成功し，現在では工業用に用いられているダイヤ モンドのほとんどが高圧合成法による粉末あるいはその 焼結体である，その後，1980年代に入ると気相合成法， すなわちガス原料から多イヤモンドを合成する方法が開 発された。メタンを $1 \%$ 程度まで水素希釈した混合ガス を原料とし，マイクロ波の放電プラズマやタングステン などの熱フィラメントによって分解・反応させる気相化 学堆積法 (CVD) である ${ }^{122}$. 気相合成法では比較的簡便 な装置により高純度ダイヤモンドを合成できること，広 い面積に薄膜を合成できることなどから，ダイヤモンド の工学的応用の可能性が大幅に拡大した.

気相合成法の成功以来，研究者らは手製の合成装置に よって合成したダイヤモンド薄膜の物性研究を精力的に 行う一方, 装置メーカーが工業用のダイヤモンド薄膜合 成装置の開発に取り組み, 筆者らのグループでも昨年, 最新の合成装置を導入した。合成方法はマイクロ波プラ ズマ CVD 法で, 最大 $5 \mathrm{~kW}$ の電力を用いて大面積成膜 と高速成長を実現している，基板サイズは 2 インチ，典 型的な合成条件では $3 \mu \mathrm{m} /$ 時でダイヤモンドが成長す る.作製したダイヤモンド薄膜の走査型電子顕微鏡 (SEM) 写真を図 1 に示す。シリコンウエハー上に多結 晶のダイヤモンドが成長しているのがわかる.

このような気相合成法によるダイヤモンド薄膜を工業 的に実用化するうえでの問題点として，成長に必要な温 度が高いために基板材料が限定されること，および成長 速度が遅いために製造コストが高いことがなどあげられ る. 同様の装置はすでに多くの納入実績があるものの， 成長速度やランニングコストの点で工業的実用化は難し く, 主に研究試料の作製用に用いられているのが現状で

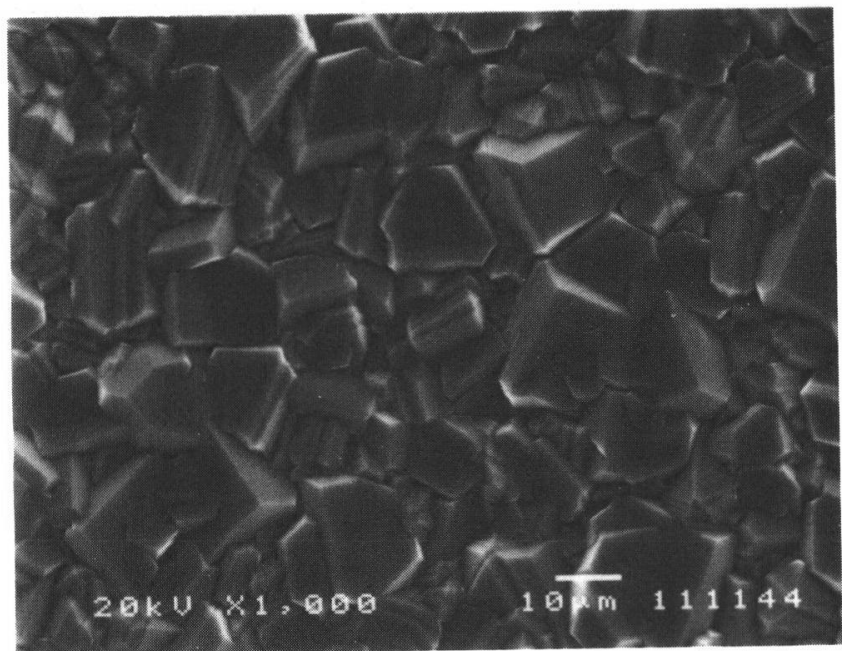

図 1 気相合成ダイヤモンド薄膜の SEM 写真

ある. 今後さらに低コストで高速成膜の技術開発が望ま れる。

\section{3. 負性電子親和力}

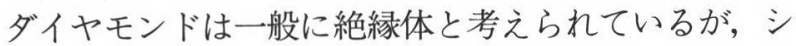
リコンと同じ結晶構造を持った共有結合性の半導体であ る.バンドギャップは間接遷移で $5.5 \mathrm{eV}$ ときわめて大き いためキャリアを熱的に励起することは難しいが，不純 物を導入すれば室温でも導電性を示す。然に産出する

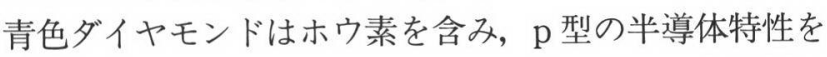
示寸ことが知られており，気相合成法においても原料が スにホウ素源のガスを混入することで $\mathrm{p}$ 型伝導の半導 体ダイヤモンドを合成することは比較的容易である.

本格的なダイヤモンドの気相合成に成功する直前の 1979年，天然のダイヤモンドにおいて負性電子親和力と いうきわめて特異な表面物性が確認された ${ }^{3)}$. 図 $2(a) に$ 示すように，半導体における電子親和力とはバンド構造

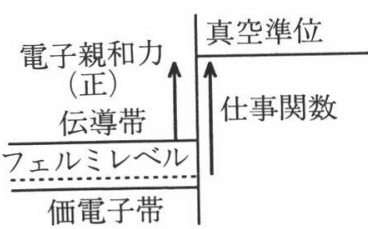

(a)

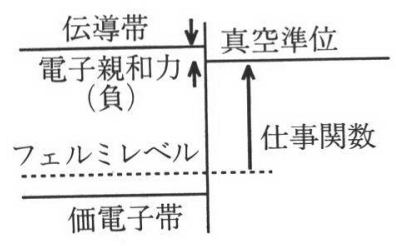

(b)
図 2 半導体のバンド図

(a)通常の正の電子親和力を持つ材料の場合 (b)負性電子親和力の場合 
における伝導帯の底と真空準位との差を意味している。 一方, 仕事関数はフェルミ準位と真空準位との差である. 金属ではフェルミ準位の電子が仕事関数を乗り越えたと きに真空中に放出されることから，電子の放出は仕事関 数に支配される，ところが半導体ではフェルミ準位には 必ずしも電子が存在するとは限らず，むしろ伝導帯の底 にいる電子が放出される場合が多いことから, 電子親和 力が重要な意味を持つようになる.

図 2 (a)のように, 普通の半導体材料では価電子带の頂 も伝導带の底も真空準位からみるとはるか下方に位置 し, 仕事関数と電子親和力はそれほど大きくは違わず, いずれも正の值となる。しかしダイヤモンドではバンド ギャップがきわめて大きいため, 図 2 (b)のように $\mathrm{p}$ 型半 導体になってフェルミ準位が価電子带に近くなった場 合，伝導带の底は真空準位に近くなりこれを越えてしま う場合がある.この状態を負性電子親和力と呼ぶ。負性 電子親和力が実現されると, 伝導帯に励起された電子は 自分から真空中に飛び出すことになり, 電子を放出しや すい状態であると考えられる。

伝導带に励起さえすれば電子が効率よく放出されると はいうものの, 実際には伝導帯は真空準位よりさらに上 にあるので, 価電子帯から伝導帯への電子の励起はきわ めて難しく，また適当な $\mathrm{n}$ 型半導体ができていないため に pn 接合で電子を注入することも容易ではない. しか し, 外部から何らかのエネルギーを与えれば励起は可能 であり, 励起さえすれば高効率で放出されることが期待 される. すなわち, 紫外光で励起する光電子放出や電子 線で励起する二次電子放出ではほかの材料に比べて非常 に高い放出効率が得られ，放電電極として用いた場合に は高い $\gamma$ 係数が期待できる.

負性電子親和力は夕゙イヤモンドの表面が水素で覆われ た場合に得られ，酸素が付着すると正の電子親和力にな ることがわかっている4). 図3は自立のダイヤモンド薄

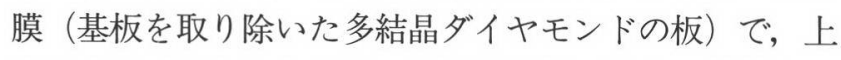
面は水素で覆われた状態, 側面と下面は酸素が付着した 状態である. 水素で覆われて負性電子親和力になった表 面ではきわめて高い効率で二次電子が放出されることに より, SEM 像が明るく輝いて見える。

\section{4.ダイヤモンド薄膜の応用分野}

ダイヤモンド薄膜の応用が期待される分野のうち, 切 削工具へのコーティングはかなり実用化が進んでいる分 野の 1 つであるが，ダイヤモンドは鉄系材料と相性が悪 く, 用途はアルミ系材料やセラミックスの加工に限定さ れる. 高い熱伝導率を利用したヒートシンクや赤外から 紫外の広い範囲の光学的透過性を利用した空材も魅力的 であるが，これらの応用にはバルクないしは厚板が必要 であり，現在の製造コストでは実用化は難しい。

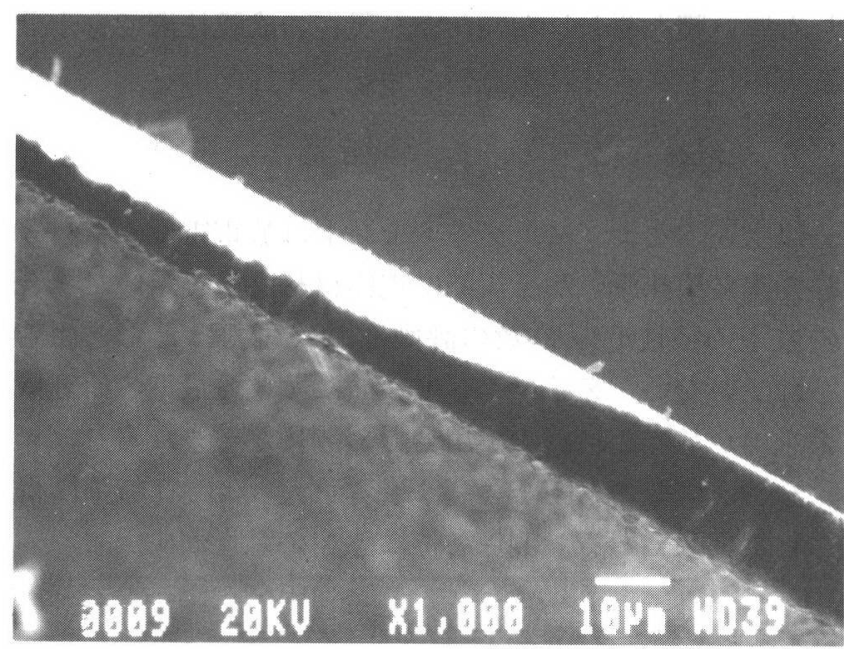

図 3 ダイヤモンド自立薄膜の断面 SEM 写真

SEM 像の明るさは, 走查している入射電子線に よって励起巳れる二次電子放出の強度を反映して いる. 表面処理によって上面は負性電子親和力, 下 面と側面は正の電子親和力となり, $\gamma$ 係数の違いか ら二次電子像の明るさが大きく異なっている。

電子材料としては半導体として電力用デバイスや将来 の超高速デバイス材料と期待されているが, 高品質な単 結晶成長技術の開発が必要である。現時点で実用化に近 い応用分野は, 表面弾性波を利用したマイクロ波フィル ター素子（SAWフィルター）の材料や高温高圧などの 特殊環境下で使用できる各種センサーデバイスの材料で ある。

以上，述べた応用分野は主にダイヤモンドのバルクの 物性を用いているため, 製造コストが重要な課題となる。 これに対し，ダイヤモンドの表面物性に注目した応用研 究が最近とくに目立つようになってきた。1つはダイヤ モンド表面の化学的不活性とドーピングによる低抵抗の 導電性に着目して, 電解夜用の電極として利用しようと する試みである。もう 1 つは先に述べた負性電子親和力 を利用して高性能の電子放出素子や冷陰極を実現しよう とするものである．液晶に代わる薄型ディスプレイとし て PDP, LED, ELなどと並んでFEDが注目され，そ の鍵を握る冷陰極の開発が課題となっているなかで, ダ イヤモンドやそのほかの炭素系新材料は高効率で安定な 電子放出材料として期待されている5).

さて, 水素で処理して負性電子親和力となったダイヤ モンド表面は非常に大きな $\gamma$ 係数を持つことから, 放電 電極や放電容器の材料としても魅力的である. ダイヤモ ンドを導体 (半導体) として用いれば放電電極として, 一方，絶縁体としては現在 PDP の放電セルに用いられ ている $\mathrm{MgO}$ に代わるコーティング材料となる可能性が ある。

これらの応用では表面物性がとくに重要であり，必ず 
しも厚い膜を要としないため，現在の成膜技術でも十分 に実用化できる分野を見いだせる可能性がある。

\section{5.おわりに}

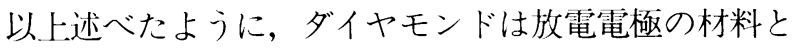
して大変興味樑いが，実際に電極材料として用いた場合 の放電の特性や $\gamma$ 係数の評価はこれまでほとんど報告 されていない，ダイヤモンド表面に関する最近の研究成 果をいかしてこれらの実用分野の開拓か望まれる。

なお，図 3 のSEM写真は筆者が大阪大学在職中に得 られた成果である。関係各位に感謝の意を表す。

\section{参考文献}

(1) S. Matsumoto, Y. Sato, M. Tsutsumi and N. Setaka : "Growth of diamond particles from methane-hydrogen gas", J. Materials Sci., 17, pp.3106-3112 (1982)

(2) M. Kamo, Y. Sato, S. Matsumoto and N. Setaka: "Diamond Synthesis from Gas Phase in Micowave Plasma”, J. Crystal Growth, 62, pp.642-644 (1983)

(3) F.J. Himpsel, J.A. Knapp, J.A. van Vechten, D.E. Eastman : "Quantum photoyield of diamond (111)-A stable negativeaffinity emitter", Phys. Rev., B20, pp.624-627 (1979)

(4) 八田章光, 伊藤利道, 平木昭夫：「半導体夕゙イヤモンド薄膜を用い た電子エミッ夕」, 電学論 A, 117, pp.233-238 (1997)

（5）八田章光, 伊藤利道, 平木昭夫：「夕゙イヤモンド薄膜を用いた電子 エミッ夕」，灾用物理， 67, pp.1410-1413（1998）

\section{書籍拄文書}

この注文書にご記入のうえ，FAXまたは郵便でお送り下さい。

\begin{tabular}{|c|c|c|c|c|}
\hline 書 & 籍 名 & 本体価格 & 注文数 & ご購入金額 \\
\hline & & & 册 & 円 \\
\hline & & & 冊 & 円 \\
\hline & & & 冊 & 円 \\
\hline & & & 册 & 円 \\
\hline & & & 冊 & 円 \\
\hline & & & 册 & 円 \\
\hline & & & 冊 & 円 \\
\hline
\end{tabular}

※お支払いは送本時同封の振替用紙でお願いします。

\section{FAX 03-5294-0102}

(社)照明学会 事務局 $\bar{T} 101-0048$ 東京都千代田区神田司町2-8-4 電話 03(5294)0101

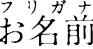
会員No.

送付先（自宅・勤務先）いずれかに○印をつけてください。 